\section{Transitional Effects of Double-lateral Drip Irrigation and Straw Mulch on Irrigation Water Consumption, Mineral Nutrition, Yield, and Storability of Sweet Cherry}

\author{
Xinhua Yin ${ }^{1,6,10}$, Lynn E. Long ${ }^{2,6}$, Xiao-Lan Huang ${ }^{1,7}$, \\ Ngowari Jaja ${ }^{1,7}$, Jinhe Bai ${ }^{3,8}$, Clark F. Seavert ${ }^{4,6}$, and Jac le Roux ${ }^{5,9}$
}

Additional index words. Prunus avium, fruit quality, leaf nutrient concentrations, soil microbial communities

Summary. A field trial was conducted on a Cherryhill silt loam soil at The Dalles, OR, from 2006 to 2008 . The impacts of switching from the traditional micro sprinkler irrigation (MS) to double-lateral drip irrigation (DD) and from no groundcover with herbicide control of weeds (NC) to in-row wheat (Triticum aestivum) straw mulching (ST) were evaluated in a split-plot design with four replicates. Irrigation water use, mineral nutrition, and productivity of 'Lapins' sweet cherry (Prunus avium) on 'Mazzard' rootstock ( $P$. avium) and soil quality were measured on a plot basis. DD reduced irrigation water consumption by $47.6 \%$ to $58.2 \%$ compared with MS. Straw mulch lowered irrigation water use by $9.7 \%$ relative to NC. Total fruit yield and fruit quality of firmness, size, and sugar at harvest were similar for the irrigation treatments. Straw mulch increased fruit size by $0.6 \mathrm{~mm}$ on average relative to NC, which could result in increased grower profitability. The DD system enhanced percentage of marketable fruit by $8.6 \%$ relative to MS. Leaf phosphorus $(\mathrm{P})$, boron $(\mathrm{B})$, zinc $(\mathrm{Zn})$, and iron $(\mathrm{Fe})$ concentrations were reduced with DD over MS; consequently, more $\mathrm{P}, \mathrm{B}$, $\mathrm{Zn}$, and Fe fertilizers might be needed under DD. Straw mulch markedly decreased the populations of flagellates and amoebae but slightly increased the population of ciliates. Straw mulch resulted in a soil microbial community with remarkably less protozoa. Overall, DD is a viable alternate irrigation system for producing sweet cherry orchards with limited water resources for irrigation. Switching from NC to ST could lower irrigation water use, reduce herbicide runoff, and protect soil from erosion.

$\mathrm{W}$ Tater management is a key production practice in sweet cherry. Impact and MS are the major orchard irrigation systems

\footnotetext{
This project was supported by USDA NRCS Conservation Innovation Grant Program, Oregon Sweet Cherry Commission, International Plant Nutrition Institute, and Oregon State University Agricultural Research Foundation.

We thank Mel Omeg and Mike Omeg for their contributions to this study.

${ }^{1}$ Department of Plant Sciences, The University of Tennessee, 605 Airways Boulevard, Jackson, TN 38301

${ }^{2}$ Department of Horticulture, Oregon State University, 400 East Scenic Drive Suite 2.278, The Dalles, OR 97058

${ }^{3}$ Horticultural Research Laboratory, USDA-ARS, 2001 South Rock Road, Fort Pierce, FL 34945

${ }^{4}$ Department of Agricultural and Resource Economics, Oregon State University, 213 Ballard Extension Hall, Corvallis, OR 97331

${ }^{5}$ Irrinet LLC, 910 East 10th Street, The Dalles, OR 97058

${ }^{6}$ Professor

${ }^{7}$ Postdoctoral Scientist

${ }^{8}$ Research Chemist

${ }^{9}$ Irrigation Specialist

${ }^{10}$ Corresponding author.

E-mail: xyin2@utk.edu.
}

in the United States (Fereres et al., 2003). These sprinkler irrigation systems wet the entire ground surface by providing water to both the tree row areas and between-row grass alleys at a relatively high rate. Because of increasing energy prices in recent years, higher production costs and lower grower profitability have been observed with these systems (Bryla et al., 2005). Furthermore, the traditional irrigation systems are not favorable for fruit storability (Bryla et al., 2003). Increased water shortages likely occur in many arid areas where orchards exist or will be planted. Thus, alternate irrigation systems with higher water use efficiency potentials are needed for orchard crops.

Drip irrigation systems are potential alternative irrigation systems to the traditional sprinkler irrigation systems (Shock et al., 2007). Drip irrigation is usually more efficient in water use than sprinkler irrigation since it provides water to only the tree row areas with no water applied to the between-row grass alleys and irrigates at a much lower rate of flow and pressure (Afolayan et al., 2007). However, limited information is available about the transitional influences of switching from sprinkler irrigation to drip irrigation on water use, growth, and productivity of sweet cherry or other orchard trees. Instead, irrigation studies have primarily focused on newly planted orchards developed using one irrigation system (Neilsen et al., 2001).

It has been documented that wetting only $20 \%$ to $50 \%$ of the root zone volume of producing mango trees (Mangifera indica) is adequate to optimize yield, assuming sufficient water is available to meet the evapotranspiration requirements during critical periods of fruit development (Spreer et al., 2009). Water use efficiency of sweet cherry may also be enhanced with increased water stress. Dehghanisanij et al. (2007) found no significant yield reductions of cherry trees associated with lowering crop evapotranspiration from $100 \%$ to $75 \%$.

Additionally, water management is found to be linked to fruit quality and storability. For instance, physiological disorders including fruit cracking and fruit quality of sweet cherries are affected by irrigation regime (Engin

\begin{tabular}{llll}
\hline $\begin{array}{l}\text { Units } \\
\begin{array}{l}\text { To convert U.S. to SI, } \\
\text { multiply by }\end{array}\end{array}$ & U.S. unit & SI unit & $\begin{array}{l}\text { To convert SI to U.S., } \\
\text { multiply by }\end{array}$ \\
\hline 0.01 & $\%$ & $\mathrm{~g} \cdot \mathrm{g}^{-1}$ & 100 \\
10 & $\%$ & $\mathrm{~g} \cdot \mathrm{kg}^{-1}$ & 0.1 \\
0.3048 & $\mathrm{ft}$ & $\mathrm{m}$ & 3.2808 \\
3.7854 & $\mathrm{gal}$ & $\mathrm{L}$ & 0.2642 \\
9.3540 & gal $/ \mathrm{acre}$ & $\mathrm{L} \cdot \mathrm{ha}^{-1}$ & 0.1069 \\
2.54 & inch $(\mathrm{es})$ & $\mathrm{cm}$ & 0.3937 \\
25.4 & inch $(\mathrm{es})$ & $\mathrm{mm}$ & 0.0394 \\
0.4536 & $\mathrm{lb}$ & $\mathrm{kg}$ & 2.2046 \\
1.1209 & $\mathrm{lb} / \mathrm{acre}$ & $\mathrm{kg} \cdot \mathrm{ha}^{-1}$ & 0.8922 \\
1.6093 & mile(s) & $\mathrm{km}$ & 0.6214 \\
1 & $\mathrm{ppm}$ & $\mathrm{mg} \cdot \mathrm{kg}^{-1}$ & 1 \\
2.2417 & ton $/ \mathrm{acre}$ & $\mathrm{Mg} \cdot \mathrm{ha}^{-1}$ & 0.4461 \\
$\left({ }^{\circ} \mathrm{F}-32\right) \div 1.8$ & ${ }^{\circ} \mathrm{F}$ & ${ }^{\circ} \mathrm{C}$ & $\left(1.8 \times{ }^{\circ} \mathrm{C}\right)+32$ \\
& & &
\end{tabular}


et al., 2009). Excessive water application can cause sweet cherry surface pitting (Patten et al., 1983), which heavily influences fruit storage, marketing, and pricing.

Ground management is another key production practice in tree fruit production affecting water use efficiency. Effective ground management can control weeds, conserve soil moisture, improve soil water infiltration and nutrient retention, enhance fruit quality, improve soil structure, and prevent soil erosion (Merwin et al., 1996; Sirrine et al., 2008). For decades, herbicide application in tree row areas along with grass alleys between tree rows has been used as the standard ground management practice in the United States (Shribbs and Skroch, 1986). This system provides a vegetation-free zone within the tree rows to minimize weed competition with trees for water and nutrients while maintaining soil structure in the alleys (Parker and Hull, 1993). Although in-row herbicide application in orchards is effective for weed control and reducing water use, it may adversely affect soil ecosystems and the environment, such as reducing soil microbial activities and elevating water contamination (Merwin et al., 1996). Furthermore, soil organic matter and organisms in orchard row areas may decrease because of lack of actively growing cover in these middle areas. All these suggest that alternate in-row ground management systems need to be developed.

Using crop straw to cover these middle row areas beneath orchard trees is emerging as a possible watersaving alternative to the traditional practice of herbicide-controlled bare middles (Forge et al., 2003; Merwin et al., 1994). A long-term field experiment on apple (Malus $\times$ domestica) concluded that trunk cross-sectional area and fruit yield of apple were enhanced because of in-row organic mulching compared with bare middles (Forge et al., 2003). Water availability, organic matter, water infiltration, saturated hydraulic conductivity, and temperatures of soil are also improved by organic mulching (Merwin et al., 1994). In addition, the leaching and runoff of nitrate- $\mathrm{N}$ and benomyl fungicide have been shown to be reduced because of organic mulching (Merwin et al., 1996). All these results imply that orchard productivity and soil quality can be improved with organic mulching.

Soil microbial communities in orchard soils have so far been poorly documented although they are crucial to various soil processes including organic matter decomposition, nitrogen transformation, etc. Soil microbial communities differed significantly depending on ground management practices in a 10-year apple trial (Laurent et al., 2008). Soil treated with preemergence residual herbicides had the fewest culturable bacteria, while soil under mowed-sod treatment had the largest population of culturable fungi; at the same time, some pests such as root-lesion nematode (Pratylenchus sp.) were greater in mowed-sod than other ground management practices (Laurent et al., 2008).

The primary objective of this study was to evaluate the impacts of switching from MS to DD and shifting from NC to ST on soil quality, irrigation water consumption, leaf nutrition, fruit yield, quality, and storability of sweet cherries.

\section{Materials and methods}

EXPERIMENTAL CONDITIONS. A field experiment was conducted from 2006 to 2008 on producing sweet cherry trees on a Cherryhill silt loam (fine-loamy, mixed, mesic Ultic Haploxeralfs) near The Dalles, OR (U.S. Department of Agriculture, 1975). This soil series has a surface layer of very dark grayish brown silt loam and a subsoil of dark brown and dark yellowish brown silt loam, sandy clay loam, and loam. The soil depth for this soil series was $\approx 40$ to 60 inches. The weather data were collected from The Dalles Downtown Weather Station, The Dalles, OR, which is $\approx 3 \mathrm{~km}$ away from the experimental site (Weather Underground, 2012).

The orchard was planted to $16 \mathrm{ft}$ between trees within row and $18 \mathrm{ft}$ between tree rows in 1999. The trees were trained to a steep leader system. The cherry cultivar was 'Lapins' on 'Mazzard' rootstock. The trees were $\approx 12$-ft tall and the canopies were $\approx 12$ $\mathrm{ft}$ in diameters before this experiment in 2006. Trees were established using MS with one sprinkler per tree and a flow rate of 15 gal of water per hour. About $100 \%$ of the orchard floor was wetted by the sprinklers. No groundcover with herbicide applications for weed control and grass alleys were used to manage this block before this study.

Two irrigation systems and two ground management systems were evaluated in a randomized complete block split-plot design with four replications during 2006-08. The two irrigation systems were DD and MS. The two ground management systems included straw mulch cover ( 6 inches thick and $10-\mathrm{ft}$ wide) and the control (no mulch or fabric cover, but herbicides were used in the $10-\mathrm{ft}$ row width to control weeds). The two irrigation systems and two groundcover systems were assigned to the main and subplots, respectively. The traditional MS treatment had one Supernet sprinkler (Netafim USA, Fresno, CA) under each tree with a capacity of 15 gal of water per emitter per hour which was placed west of the tree at $3 \mathrm{ft}$ from the tree trunk. The wetted area was $18 \mathrm{ft}$ in diameter. The micro sprinklers used in MS were spinners, which provided uniform water coverage to $100 \%$ of the total ground surface including the tree row areas and between-row grass alleys. The DD system used pressure compensating drip tubing (RAM, Netafim USA) with a dripper every $2 \mathrm{ft}$ and a capacity of $0.50 \mathrm{gal}$ of water per emitter per hour. Thus, each tree received 15 gal of water per hour under MS but only 8 gal per hour under DD. Because each dripper wetted a circle with a radius of 18 inches and two adjacent drippers were only $2 \mathrm{ft}$ apart on the same drip line, the wet zones of the two adjacent drippers on the same drip line were overlapped 6 inches. Wheat straw was put on the ground surface with a thickness of 6 inches in Mar. 2006 for ST. No cover, bare soil conditions for the control NC subplots were established using glyphosate at $0.15 \mathrm{gal} /$ acre mixed with 16 gal/acre of water sprayed on the soil in early June each year. Each subplot consisted of seven trees; the central five trees were used for data collection, sampling, and fruit harvest. Fertilizer applications and pest control for all treatments followed the standard practices commonly used for commercial production in the region. Nitrogen fertilization is usually applied in the spring at a rate of 80 to $100 \mathrm{lb} /$ acre nitrogen. Phosphorus and potassium $(\mathrm{K})$ applications are based on soil testing results. 
SOIL MOISTURE MONITORING AND IRRIGATION SCHEDULING. Irrinet LLC (The Dalles, OR) was contracted to monitor soil moisture status and provide irrigation schedules for the trial. Irrigation was conducted separately for each subplot on a weekly basis from May to October each year according to soil moisture content, which was monitored weekly with a neutron probe meter (CPN 503DR Hydroprobe; Campbell Pacific Nuclear Co., Martinez, CA). The experiment called for the moisture of soil beneath producing sweet cherry trees to be kept above $70 \%$ of field capacity before fruit set, $80 \%$ to $100 \%$ between fruit set and harvest, $70 \%$ to $90 \%$ for August postharvest, and $60 \%$ to $70 \%$ in September and October. The field water capacity of the soil was 3.2 inches per foot of soil. All treatments were irrigated as needed to stay within these bounds, and volumes of irrigation were recorded during each irrigation event. This irrigation duration is typically used in the region.

A neutron probe access tube was installed in each subplot at the beginning of the trial. The tube was 1.5 inches Class 125 polyvinyl chloride tubing cut to a length of $3.5 \mathrm{ft}$. The tube protruded 4 inches aboveground surface for the probe to rest on and has 2 inches extra at the bottom to allow the probe to stay off the bottom of the tube. Because these were well-drained soils and no subsurface ponding occurred, the access tubes were not sealed at the bottom. Each tube was numbered and capped to keep moisture and debris out. Tubes were positioned under the canopy of the tree, at a healthy tree with buffer trees on either side to minimize lateral effects. All tubes were exactly the same distance from the tree. In the case of MS, the tube was placed midway between the tree and the micro sprinkler and located in the tree row. In $\mathrm{DD}$, the two lines were $3 \mathrm{ft}$ apart and the access tube was installed midway between the drip lines and between drip emitters (which were $2 \mathrm{ft}$ ) and at the same distance from the tree as in the MS treatments. Because spinning micro sprinklers provided uniform water coverage to $100 \%$ of the total ground surface (including the tree row areas and between-row grass alleys), where we placed the access tubes does not matter under MS. Under the DD system, the access tubes were placed just at the connecting point between the two wet zones resulted from the two drip lines. Because over-irrigation did not exist in this study based on our irrigation recommendation, the place where the access tubes were placed should have the same moisture content as most other areas in the two wet zones from the two drip lines.

The neutron probe was calibrated to display soil moisture in millimeters per meter. The probe was calibrated using actual soil samples and a combination for volumetric and gravimetric water contents. Calibration of the high-moisture end was done in the soil at a 12-inch depth. A hole was dug to an 11-inch depth of soil with the bottom leveled. A thinwalled aluminum cylinder of a known volume was driven into the soil at the bottom of the hole. An undisturbed sample of in situ soil with known volume was extracted at a 12 -inch depth. This sample was weighed and then dried at $100^{\circ} \mathrm{C}$ for $24 \mathrm{~h}$; the loss of weight was measured. With the known volume of dried soil, relative density of the soil and soil moisture content was calculated. Next, a hole of exactly 1.5-inch diameter was augered in the soil near that location. An access tube was inserted into that hole. The neutron probe was lowered to read at an average depth of 12 inches. The neutron probe was then calibrated in the soil at 12-inch depth to give the same reading as that calculated with the volumetric method. To minimize lateral variation of soil moisture because of irrigation system nonuniformity, this procedure was performed in spring when the trees were bare and the soil profile was filled with rain water.

Because naturally occurring dry soil could not be found in the spring, a soil sample of $440 \mathrm{lb}$ was taken from the orchard and dried to a moisture level below what would be found in the orchard. The soil sample was packed into a barrel to simulate in situ soil bulk density and was then used for the determination of the soil moisture calibration curve. The same process as used for the determination of the high-moisture end was used for determining the low-moisture end. The calibration curve was a straight line in the following formula: moisture = neutron count ratio $\times \mathrm{A}+\mathrm{B}$, where $\mathrm{A}$ is the coefficient to convert neutron probe count ratio to moisture content and $\mathrm{B}$ is a constant equal to the $y$-intercept when $\mathrm{A}$ is zero.

During installation of the access tubes, soil moisture status was assessed by an experienced consultant to estimate the soil moisture status at each depth. Probe readings were then taken at each depth with the calibrated neutron probe. Estimated $100 \%$ field capacity of the soil at each depth was then calculated by prorating the probe reading with the hand-feel soil moisture observations and working back to what the water content would be at $100 \%$. In this way, the $100 \%$ field capacity of the soil can be calculated fairly accurately even when the soil is tested while not at full capacity. These calculated field capacities were entered into the Probe Schedule (Irrinet LLC) software as the full field capacity of the profile at each depth. The 100\% field capacity was refined over time after several cycles of wetting and drying by observing the drainage pattern within the soil and direct hand probing of soil moisture.

Soil moisture readings were taken at $6,12,18,24,30$, and 36 inches in the soil profile once per week on the same day and time. Data were stored, processed, and displayed with the Probe Schedule irrigation scheduling software. The software makes use of daily weather data, moisture holding capacity of the soil, and crop coefficients to model the daily water use and soil moisture content. The remaining time to the preset refill point is projected based on the current rates of extraction, current weather, and water status on the day, providing the grower with a projected date and volume to irrigate.

The following water balance relationship was used to determine the irrigation amount:

$$
I+P-R=E T c+D+S W
$$

where the terms on the left-hand side of the above equation represent the applied irrigation water $(I)$, precipitation $(P)$, and surface runoff $(R)$. The sum of these three terms represents the net addition of water to the soil profile over a time period of interest. On the right side of the equation are estimated $E T c$, drainage or deep percolation $(D)$, and the water storage change $(S W)$ of soil moisture profile. Each of the terms in the above equation represents water flows or storage 
changes over some given time interval. All of the terms in the equation are positive except for $D$ and $S W$, which may be either positive or negative depending on the direction of the water flow (upward or downward flow) (Jury et al., 1991).

The Probe Schedule program estimates crop water use $(E T c)$ by using the modified Penman equation (Jensen et al., 1971). Surface runoff in this study was zero because of the control of water application and rainfall events being lower than the amount of water required to replenish the top $36 \mathrm{~cm}$ of the soil profile to field capacity. Notable deep percolation or drainage only occurred when soil moisture in the deepest soil layer was over $100 \%$ of field capacity. Drainage was estimated by expanding the formula used for calculating ETc and only after the crop coefficient has been accurately determined. If in the formula $(I+P-R=$ $E T c+D+S W$ ), there was no irrigation, rain, or runoff in a given period, then $0=E T c+D+S W$ or $D=-S W-$ $E T c$ (with no irrigation or rain, $S W$ will be negative). In this trial, drainage did not occur because care was taken not to overfill the profile.

LEAF AND SOIL SAMPLING AND ANALYSIS. A leaf sample was taken randomly from each subplot in August, $\approx$ l month after fruit harvest each year. The samples were collected from the same trees and under similar weather conditions each season. Each sample consisted of 30 new but fully developed midshoot leaves from current year shoots at 5 - $\mathrm{ft}$ level above the ground in the tree canopy. All samples were cleaned, oven-dried at $65^{\circ} \mathrm{C}$, and ground to pass through a l-mm sieve. Total nitrogen $(\mathrm{N})$ in leaf was determined using a combustion method with a nitrogen/carbon analyzer (1500 series; Carlo Erba Instruments, Milan, Italy) (Gavlak et al., 1994). Total P, K, calcium $(\mathrm{Ca})$, magnesium $(\mathrm{Mg})$, sulfur (S), B, Fe, manganese (Mn), copper $(\mathrm{Cu})$, and $\mathrm{Zn}$ were extracted by digesting the sample in a microwave (MDS 2100; CEM Corp., Matthews, NC) using nitric acid and hydrogen peroxide, and the digest was analyzed on an inductively coupled plasma spectrometer (model 1100; Thermo Jarrell Ash, Franklin, MA) (Gavlak et al., 1994).

Soil sampling was conducted at the depth interval of 0 to 12 inches from each subplot in August of each year. Ten cores with a $\mathrm{l}$-inch-diameter soil probe were randomly collected from under the five central trees in each subplot to make a composite sample after removing visible tree and weed residues from the soil surface. Each sample was placed in a soil-sampling bag and then stored in a cold storage room at $1{ }^{\circ} \mathrm{C}$. All samples were air dried, ground to pass through a $2-\mathrm{mm}$ sieve, and thoroughly mixed. Soil available ammonium $\left(\mathrm{NH}_{4}{ }^{+}\right)$, nitrate $\left(\mathrm{NO}_{3}{ }^{-}\right), \mathrm{P}, \mathrm{K}, \mathrm{Ca}, \mathrm{Mg}, \mathrm{S}, \mathrm{B}, \mathrm{Zn}, \mathrm{Mn}$, and $\mathrm{Cu}$ were extracted using the Mehlich III method (Mehlich, 1984). Soil amino sugar $\mathrm{N}$ was extracted with sodium hydroxide $(\mathrm{NaOH})$ (Khan et al., 2001). Soil total $\mathrm{N}$ was determined by dry combustion (Gavlak et al., 1994). Soil acidity (pH) was determined in a $1: 1$ (soil:water) solution (Watson and Brown, 1998), and organic matter was measured using the loss-on-ignition method (Combs and Nathan, 1998). Soil bulk density was determined for the samples collected at the end of experimentation in Fall 2008.

Analyses of active bacteria and fungi, total bacteria and fungi, protozoa, and nematodes were conducted by Microbial Matrix Systems Inc. (Tangent, OR) using the soil samples which were collected on an individual subplot basis after fruit harvest in Fall 2008. Active and total bacteria numbers were directly estimated using the fluorescein diacetate method (Ingham and Klein, 1984; Lodge and Ingham, 1991) and fluorescein isothiocyanate method (Babiuk and Paul, 1970), respectively. Active and total fungi were estimated using the fluorescein diacetate method and phase contrast microscopy, respectively (Ingham and Klein, 1984). Calculations of bacterial and fungal biomass were based on the method of Paul and Clark (1988). Protozoa were determined with the most probable number technique (Darbyshire et al., 1974). Nematodes were measured using the Baermann funnel and differential interference contrast microscopy method (Anderson and Coleman, 1977).

FRUIT YIELD, QUALITY, AND STORABILITY DETERMINATIONS. Fruit yield was determined by harvesting five central trees from each subplot each year. Fruit quality attributes including firmness, size, and sugar were measured on a subplot basis each season. Fruit firmness and size were assessed using 30 fruit per plot on a fruit firmness tester (FirmTech 2; BioWorks, Stillworks, OK). Fruit sugar was determined using a digital refractometer (PRl01 $\alpha$; Atago Co., Tokyo).

Fruit skin color was determined with a chromameter (model CR-2500d; Minolta, Tokyo) using 50 fruit per plot in 2006 and 2007 only. The setting conditions were as follows: Mask/Gloss-M/SCI; ultraviolet Setting-ultraviolet $100 \%$; IlluminantlD-65(standard); Illuminant 2-D-65; Observer- $10^{\circ}$. Color parameters were expressed as tristimulus colorimetric measurements of $L^{*}, a^{*}, b^{*}, C^{*}$, and hue angle. $L^{*}$ indicates lightness. A positive $a^{*}$ value indicates redness, and a negative $a^{*}$ value indicates greenness. A high positive $b^{*}$ value indicates more yellow color, and a negative $b^{*}$ blue color. The chroma $\left(C^{*}\right)$ value, calculated as $C^{*}=\left(a^{* 2}+b^{* 2}\right)^{1 / 2}$, indicates color intensity or saturation. Hue angle, a parameter that has been shown to be effective in predicting visual color appearance, was calculated using the formula $b^{\circ}=\tan ^{-1}\left(b^{*} / a^{*}\right)$, where $0^{\circ}$ or $360^{\circ}=$ red-purple, $90^{\circ}=$ yellow, $180^{\circ}=$ green, and $270^{\circ}=$ blue (Sapers, 1994).

Visual evaluation of fruit surface pitting was conducted after the fruit had been stored in a cold storage room at $-1{ }^{\circ} \mathrm{C}$ for 3 weeks. Five categories consisting of excellent, slightly pitted, pitted, bruised, and pitted plus bruised fruit were used in this evaluation. The percentage of each category was then calculated. The percentage of marketable fruit consisted of the percentages of both excellent fruit and slightly pitted fruit based on the local market practice.

Statistical analysis. Analysis of variance (ANOVA) for each measurement was conducted separately for each year and 3 years combined using the ANOVA procedure in SAS (version 9.2; SAS Institute, Cary, NC). For the analyses of each individual year data, a randomized complete block split-plot model was used with irrigation systems as the main plot factor and groundcovers as the subplot factor. The main effects of main and subfactors and the two-way interaction of main and subfactors were included in the model. For the analyses of the 3-year combined data, the same model as used for each individual year data were used but year was added into the model as a random factor, and all the interactions of year with the main 
factors, subfactors, or both were also added in the model.

Mean separations for each measurement were accomplished using the Fisher's protected least significant difference test (Kuehl, 1994). Probability levels less than 0.05 were designated as significant. However, for soil microbes, nematodes, and protozoa, probability levels less than 0.10 were categorized as significant because the assays for measuring these soil biological attributes generated higher variability than those used in the other measurements.

\section{Results and discussion}

Presentation of the results in this section focuses on the main effects of main and subtreatments because the interaction of main and subtreatments for each individual year data and the interactions of main and subtreatments and year for the 3-year combined data were statistically insignificant in all measurements in this study.

Precipitation for Oct. 2005Sept. 2006 at $470.7 \mathrm{~mm}$ was $26.9 \%$ higher than the 30-year average, while 2007 and 2008 were both dry and had annual precipitations $10.9 \%$ and $18.3 \%$ lower than the 30 -year average, respectively (Fig. 1). Annual precipitation was not uniformly distributed throughout the year. Most precipitation events occurred in the winter and spring (October to April, $86.3 \%$ of the yearly total according to the 30-year average data); seasonal drought was normal in summer and fall. Monthly and annual temperatures were similar for the 3 years of study and were close to the 30 -year averages (data not presented).

IRRIGATION WATER CONSUMPTION. One of the largest benefits with DD was reducing irrigation water use. Irrigation water consumption was reduced by $47.6 \%, 56.5 \%$, and $58.2 \%$ under DD compared with the MS irrigation in 2006, 2007, and 2008, respectively, averaged over the two groundcover systems (Table 1). On the average of 3-year data, irrigation water consumption was reduced by $10.8 \%$ with ST relative to NC (Table 1). However, irrigation water consumption was unaffected by either fruit yield or annual precipitation in this study.

In the orchard block used in this study, the spacing between two adjacent tree rows was $18 \mathrm{ft}$; there was

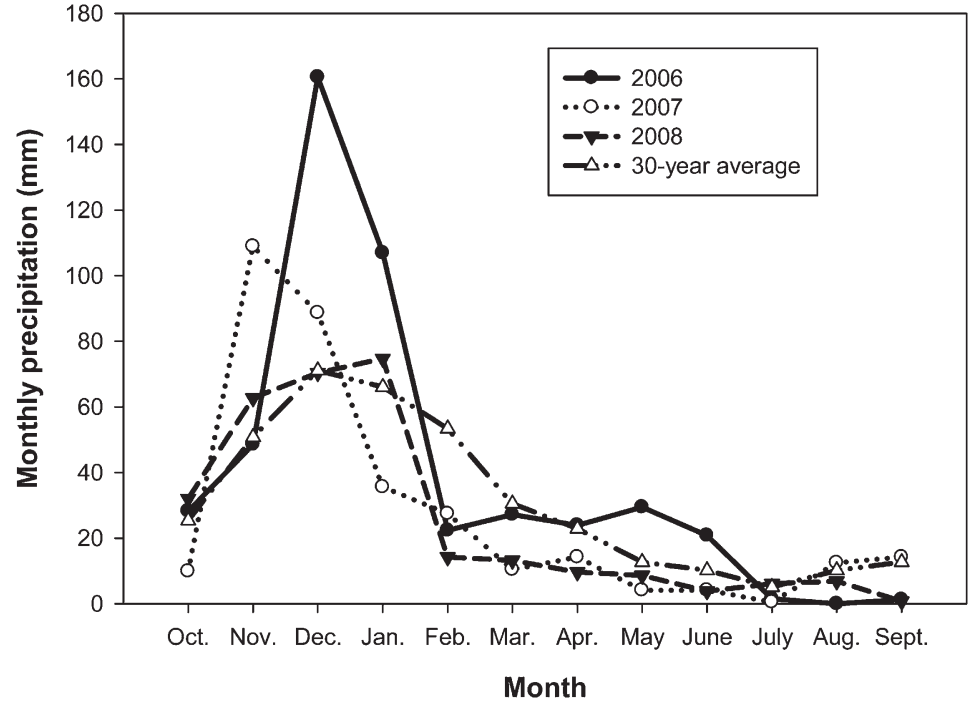

Fig. 1. Monthly precipitation of the experimental period (2006-08) compared with the 30 -year averages at the experimental site at The Dalles, OR; $1 \mathrm{~mm}=0.0394 \mathrm{inch}$.

a 10 -ft-wide grass alley in the middle between the two adjacent tree rows. Therefore, $\approx 55 \%$ of the ground surface was used to grow grass alleys, and only $45 \%$ of the ground surface was bare soil surface under the tree rows in this orchard. In the MS system, irrigation water was supplied to the entire ground surface including both the bare soil surface under the tree rows and the grass alleys between the tree rows. However, under the DD system, irrigation water was provided only to a large portion of the bare soil surface under the tree rows and the grass alleys did not receive any irrigation water at all. Thus, the reduction of surface evaporation and minimal cover crop water use were the main reason why DD saved $\approx 50 \%$ of irrigation water. Similarly, Bryla et al. (2003) reported that drip irrigation reduced irrigation water use by over $50 \%$ compared with MS on peach trees (Prunus persica) in central California. Overall, our results suggest that switching from MS to DD and from NC to ST are viable approaches to reduce irrigation water use on already established producing sweet cherry orchards. Our results can be applied to sweet cherry trees even on coarse texture soils because the trees' water requirement is the same if the trees are of the same size. However, since water holding capacity was lower in coarse texture soils, irrigation to the coarse texture soils need to be conducted at a lower rate each time but more often during the season.
Fruit yield AND QUALity. Fruit yield varied remarkably with year regardless of irrigation and groundcover system (Table 1). The 2005 growing season was extremely dry, which resulted in extremely low yields in 2005 and thus extremely high crop loading in 2006. Even though chemical thinning was conducted for the entire test in 2006, the crop loading was still far heavier than normal growing seasons. Because of the extremely heavy crop loading, the yields in 2006 were extremely high. The low yields of 2008 were related to the cold and wet weather conditions early in the season, which caused inadequate bee activity for pollination. Fruit yield did not differ between the two irrigation systems averaged over the two groundcover systems in any season. There was no yield response to $S \mathrm{~T}$ over NC either. Our results imply that switching from MS to DD and shifting from NC to ST did not reduce fruit yields during the first 3 years of transition on producing sweet cherry orchards.

Fruit quality at harvest is crucial in sweet cherry marketing and pricing. Straw mulch increased fruit size (diameter) by $2.1 \%(0.6 \mathrm{~mm})$ relative to $\mathrm{NC}$ averaged over the two irrigation systems and the 3 years of study (Fig. 2). Since sweet cherry price is highly and positively related to fruit size, the increase of $0.6 \mathrm{~mm}$ in fruit size could result in remarkable increases in grower profitability with the application of ST. Fruit color indices $\left(L^{*}, a^{*}, b^{*}, C^{*}\right.$, and hue angle) 
were unaffected by irrigation system in 2006 and 2007 or by groundcover system in 2006 (Table 2). However, $L^{*}, a^{*}, b^{*}, C^{*}$, and hue angle values were all reduced under ST compared with NC in 2007 which was a dry year, indicating that the drought stress under NC induced fruit to be in deeper red color.

Fruit STORABILITy. Fruit surface pitting in sweet cherry has long been a very common and major problem in the fresh market (Porritt et al., 1971). It is one of the leading causes of price reductions and product rejections from the fresh market. Our results showed that marketable fruit production is related to irrigation system. Percentage of marketable (excellent and slightly pitted) fruit showed an increase of $9.1 \%, 6.6 \%$, and $9.5 \%$ although not statistically significant with DD compared with MS in 200608 , respectively (Table 3 ). Overall, DD significantly increased marketable fruit by $8.6 \%$ by reducing fruit surface pitting when averaged over the 3 -year data. No such benefits were observed with ST relative to NC in any season (data not presented). In addition, percentage of marketable fruit varied markedly with growing season (Table 3 ).

It has been found that fruit pitting of sweet cherries is linked to a variety of factors such as water management (Patten et al., 2006). Patten et al. (2006) reported that extensive irrigation or prolonged water uptake by fruit during heavy rains promotes fruit softening, and thus increases fruit pitting of sweet cherries. Trees received much less water under DD than with MS, which might make fruit possessing less moisture; this phenomenon may at least partially explain why trees under DD had less fruit surface pitting and higher marketable fruit production in this study.

LEAF NUTRIENT CONCENTRATION AFTER FRUIT HARVEST. Leaf P concentration $\approx 1$ month after harvest was reduced by $23.1 \%, 18.2 \%$, and $26.1 \%$ with DD relative to MS in 2006-08, respectively (Table 4 ). Leaf $\mathrm{K}$ level was lowered with DD in 2008. Concentrations of other macro nutrients including $\mathrm{N}, \mathrm{Ca}, \mathrm{Mg}$, and $\mathrm{S}$ in leaf were unaffected by shifting from MS to DD. DD decreased leaf $\mathrm{B}$ concentration by $6.0 \%, 7.9 \%$, and $9.6 \%$, respectively, in 2006-08 compared with MS. Zinc concentration in leaf
Table 1. Effects of double-lateral drip irrigation and straw mulch on irrigation water consumption and fruit yield of sweet cherry at the Dalles, OR, during 2006-08.

\begin{tabular}{|c|c|c|c|}
\hline$\underline{\mathrm{Yr}}$ & Treatment $^{\mathrm{x}}$ & $\begin{array}{c}\text { Irrigation water } \\
\text { consumption }(\mathrm{mm})^{\mathrm{y}}\end{array}$ & Fruit yield $\left(\mathrm{Mg} \mathrm{ha}^{-1}\right)^{\mathrm{y}}$ \\
\hline \multirow{6}{*}{2006} & MS & 730.5 & 32.7 \\
\hline & DD & 382.8 & 29.0 \\
\hline & Significance $^{x}$ & * & NS \\
\hline & $\mathrm{NC}$ & 569.7 & 31.2 \\
\hline & ST & 543.6 & 30.5 \\
\hline & Significance & NS & NS \\
\hline \multirow[t]{6}{*}{2007} & MS & 851.2 & 16.1 \\
\hline & DD & 370.0 & 16.5 \\
\hline & Significance & * & NS \\
\hline & $\mathrm{NC}$ & 662.8 & 15.7 \\
\hline & ST & 558.4 & 16.8 \\
\hline & Significance & NS & NS \\
\hline \multirow[t]{6}{*}{2008} & MS & 755.9 & 9.9 \\
\hline & DD & 315.9 & 9.8 \\
\hline & Significance & * & Ns \\
\hline & $\mathrm{NC}$ & 557.4 & 9.3 \\
\hline & ST & 514.5 & 10.4 \\
\hline & Significance & NS & NS \\
\hline \multirow[t]{6}{*}{ Average } & MS & 779.2 & 19.6 \\
\hline & DD & 356.2 & 18.4 \\
\hline & Significance & $* *$ & Ns \\
\hline & $\mathrm{NC}$ & 596.7 & 18.7 \\
\hline & ST & 538.8 & 19.2 \\
\hline & Significance & * & NS \\
\hline
\end{tabular}

${ }^{\mathrm{z}} \mathrm{DD}=$ double-lateral drip irrigation, $\mathrm{MS}=$ micro sprinkler irrigation, $\mathrm{NC}=$ no groundcover with herbicide control of weeds, ST $=$ in-row wheat straw mulching.

${ }^{\mathrm{y}} \mathrm{l} \mathrm{mm}=0.0394$ inch, $1 \mathrm{Mg} \cdot \mathrm{ha}^{-1}=0.4461 \mathrm{ton} /$ acre .

${ }^{\mathrm{x} *}$ and $* *$ indicate treatment effect is significant at $5 \%$ and $1 \%$ probability level, respectively, based on the $F$ test; nonsignificant effect is denoted by ns.

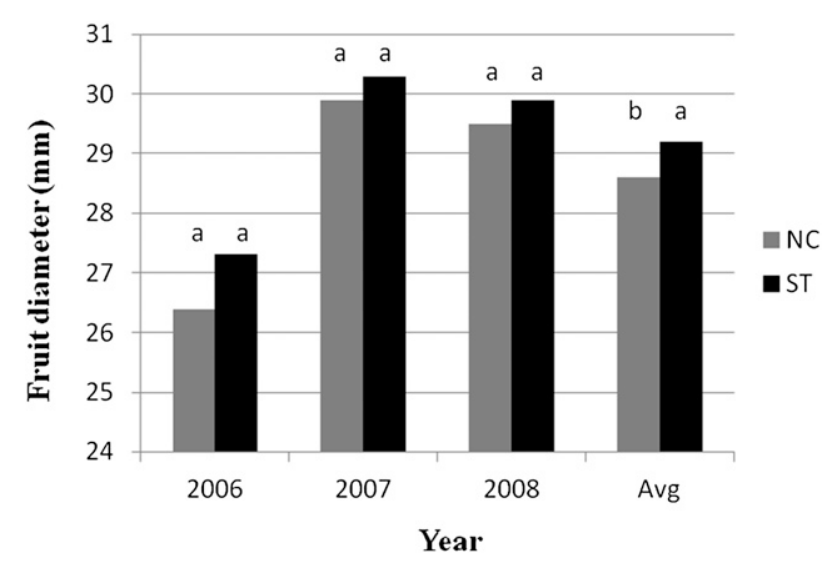

Fig. 2. Effects of straw mulch (ST) and herbicide strip (NC) on fruit size of sweet cherry at harvest averaged over the two irrigation systems and on 3-year averages at The Dalles, OR during 2006-08. Values of treatments within year or average followed by the same letter are not significantly different at $0.05 P$ level based on the $F$ test; $1 \mathrm{~mm}=0.0394$ inch. 
was lowered by $20.4 \%$ in 2006 and $15.3 \%$ in 2007 because of the switch from MS to DD. In addition, DD reduced leaf $\mathrm{Fe}$ concentration in 2006 and 2008, and $\mathrm{Cu}$ level in 2006 relative to MS. The reductions in leaf nutrient concentrations with DD might be attributed to the markedly reduced root volume receiving irrigation water. The wetted ground area was only $\approx 33 \%$ with DD relative to MS. Therefore, it may need to apply higher rates of $\mathrm{P}, \mathrm{B}, \mathrm{Zn}$, and Fe fertilizers in the wetted ground producing sweet cherry orchards during the transitional period. However, fertilizers for DD can be applied via areas if $\mathrm{DD}$ is used to replace MS on

fertigation into the root zone that may increase fertilizer use efficiency.

Based on the leaf composition standards for sweet cherry (Leece, 1976), leaf concentrations of macro nutrients including $\mathrm{N}, \mathrm{P}, \mathrm{K}, \mathrm{Ca}$, and $\mathrm{Mg}$ were in the normal ranges regardless of irrigation and groundcover treatment in this study, while concentrations of macronutrient $S$ and micronutrients $\mathrm{Fe}, \mathrm{Cu}$, and $\mathrm{Mn}$ were a little below normal, and micronutrient B is slightly higher than normal (Table 4).

SOIL MICROBIAL COMMUNITIES AND SOIL QUALITY BY THE END OF TRIAL. Protozoa are single-celled animals that feed primarily on bacteria.

Table 2. Effects of straw mulch and herbicide strip on fruit color of sweet cherries at harvest averaged over the two irrigation systems at the Dalles, OR, during 2006-07.

\begin{tabular}{|c|c|c|c|c|c|c|}
\hline \multirow[b]{2}{*}{$\underline{Y r}$} & \multirow[b]{2}{*}{ Treatment $^{\mathrm{z}}$} & \multicolumn{5}{|c|}{ Color $^{\mathrm{y}}$} \\
\hline & & $L^{*}$ & $a^{*}$ & $b^{*}$ & $C^{*}$ & Hue angle $\left(^{\circ}\right)$ \\
\hline \multirow[t]{3}{*}{2006} & $\mathrm{NC}$ & 27.3 & 12.1 & 2.68 & 12.4 & 12.0 \\
\hline & ST & 27.2 & 12.4 & 2.77 & 12.7 & 12.2 \\
\hline & Significance $^{\mathrm{x}}$ & NS & NS & NS & NS & NS \\
\hline \multirow[t]{3}{*}{2007} & $\mathrm{NC}$ & 26.9 & 17.6 & 5.32 & 18.4 & 15.9 \\
\hline & ST & 26.3 & 15.0 & 4.16 & 15.6 & 14.6 \\
\hline & Significance & * & $*$ & * & * & * \\
\hline
\end{tabular}

${ }^{2} \mathrm{NC}=$ no groundcover with herbicide control of weeds, ST $=$ in-row wheat straw mulching.

${ }^{y} L^{\star}$ indicates lightness. A positive $a^{*}$ value indicates redness, and a negative $a^{*}$ value indicates greenness. A high positive $b^{*}$ value indicates more yellow color, and a negative $b^{*}$ blue color. The chroma $\left(C^{*}\right)$ value, calculated as $C^{\star}=\left(a^{\star 2}+b^{\star 2}\right)^{1 / 2}$, indicates color intensity or saturation. Hue angle, a parameter that has been shown to be effective in predicting visual color appearance, was calculated using the formula $b^{\circ}=\tan ^{-1}\left(b^{*} / a^{*}\right)$, where $0^{\circ}$ or $360^{\circ}=$ red-purple, $90^{\circ}=$ yellow, $180^{\circ}=$ green, and $270^{\circ}=$ blue

${ }^{\mathrm{*} *}$ indicates treatment effect is significant at $5 \%$ probability level based on the $F$ test; nonsignificant effect is denoted by Ns.
They are classified into three categories of ciliates, amoebae, and flagellates based on their morphology. In this study, populations of flagellates and amoebae and total protozoa were substantially reduced by $81.8 \%$, $98.0 \%$, and $96.2 \%$, respectively, with ST compared with NC by the end of 3-year experimentation in Fall 2008 (Table 5). However, ciliates were enhanced by $37.5 \%$ with ST. Our results suggest that ST has greater but negative impacts on flagellates and amoebae and less but positive effects on ciliates; straw mulch results in a soil microbial community with remarkably less protozoa, which may reduce the release of nutrients from organic sources in the soil. Therefore, greater rates of fertilizers may be needed for orchards under ST to compensate for the reduced nutrient release from organic sources in the soil. Our results are different from those in fields of corn (Zea mays) grown with white clover (Trifolium repens) living mulch in Japan, which showed increased protozoa population under white clover living mulch (Nakamoto and Tsukamoto, 2006) possibly because white clover mulches was a living mulch with roots, whereas wheat straw was an applied mulch, or they are different in chemical compositions.

Contents of individual nematodes (bacteria-feeders, fungal-feeders, rootfeeders) and total nematodes in the soil were numerically higher although not

Table 3. Effects of double-lateral drip irrigation and micro sprinkler irrigation on the percentages of fruit surface pitting and marketable fruit of sweet cherry after cold storage at $-1{ }^{\circ} \mathrm{C}\left(30.2^{\circ} \mathrm{F}\right)$ for 3 weeks averaged over the two groundcover systems at The Dalles, OR, during 2006-08.

\begin{tabular}{|c|c|c|c|c|c|c|c|}
\hline Yr & Treatment $^{\mathrm{z}}$ & Excellent (\%) & $\begin{array}{l}\text { Slightly } \\
\text { pitted (\%) }\end{array}$ & Pitted (\%) & Bruised (\%) & $\begin{array}{c}\text { Pitted and } \\
\text { bruised (\%) }\end{array}$ & $\begin{array}{c}\text { Marketable } \\
\text { fruit }(\%)^{\mathrm{y}}\end{array}$ \\
\hline \multirow[t]{2}{*}{2006} & MS & 42.1 & 27.1 & 16.4 & 10.5 & 3.9 & 69.2 \\
\hline & Significance $^{\mathrm{x}}$ & * & NS & * & NS & NS & NS \\
\hline 2007 & MS & 22.2 & 32 & 24 & 14.3 & 7.5 & 54.2 \\
\hline \multirow[t]{3}{*}{2008} & MS & 8.8 & 49.9 & 33.0 & 3.0 & 5.3 & 58.7 \\
\hline & $\mathrm{DD}$ & 10.8 & 53.5 & 21.6 & 7.2 & 6.9 & 64.3 \\
\hline & Significance & NS & NS & NS & NS & NS & NS \\
\hline Average & MS & 24.4 & 36.3 & 24.5 & 9.3 & 5.6 & 60.7 \\
\hline
\end{tabular}

${ }^{2} \mathrm{DD}=$ double-lateral drip irrigation, $\mathrm{MS}=$ micro sprinkler irrigation.

y The percentage of marketable fruit consisted of the percentages of both excellent fruit and slightly pitted fruit based on the local market practice.

${ }^{x *}$ indicates treatment effect is significant at $5 \%$ probability level based on the $F$ test; nonsignificant effect is denoted by NS. 
Table 4. Effects of double-lateral drip irrigation and straw mulch on leaf nutrient concentrations of sweet cherry after harvest at The Dalles, OR, during 2006-08.

\begin{tabular}{|c|c|c|c|c|c|c|c|c|c|c|c|c|}
\hline \multirow[b]{2}{*}{ Yr } & \multirow[b]{2}{*}{ Treatment $^{\mathrm{z}}$} & \multicolumn{7}{|c|}{ Macronutrient $\left(\mathrm{g} \cdot \mathrm{kg}^{-1}\right)^{\mathrm{y}}$} & \multicolumn{4}{|c|}{ Micronutrient $\left(\mathrm{mg} \cdot \mathrm{kg}^{-1}\right)^{x}$} \\
\hline & & $\mathbf{N}$ & $\mathbf{P}$ & $\mathbf{K}$ & $\mathrm{Ca}$ & Mg & $S$ & $\mathbf{B}$ & $\mathrm{Fe}$ & Mn & $\mathrm{Cu}$ & $\mathrm{Zn}$ \\
\hline \multirow[t]{6}{*}{2006} & MS & 22.8 & 3.9 & 25.3 & 19.5 & 4.2 & 1.6 & 77.1 & 99.1 & 41.2 & 5.5 & 19.1 \\
\hline & $\mathrm{DD}$ & 23.1 & 3.0 & 22.4 & 18.0 & 4.1 & 1.7 & 72.5 & 88.0 & 43.6 & 4.7 & 15.2 \\
\hline & Significance $^{w}$ & NS & * & NS & NS & NS & NS & * & * & NS & * & * \\
\hline & $\mathrm{NC}$ & 22.7 & 3.4 & 24.1 & 17.8 & 4.2 & 1.6 & 75.1 & 90.9 & 41.9 & 4.8 & 18.9 \\
\hline & ST & 23.2 & 3.5 & 23.7 & 19.7 & 4.1 & 1.7 & 73.7 & 95.6 & 43.1 & 5.2 & 15.7 \\
\hline & Significance & NS & NS & NS & NS & NS & NS & NS & NS & NS & NS & * \\
\hline \multirow[t]{6}{*}{2007} & MS & 25.5 & 3.3 & 26.6 & 14.2 & 4.0 & 1.5 & 75.9 & 84.8 & 46.0 & 6.0 & 31.4 \\
\hline & $\mathrm{DD}$ & 24.9 & 2.7 & 25.1 & 13.3 & 4.1 & 1.5 & 69.9 & 90.5 & 46.0 & 5.5 & 26.6 \\
\hline & Significance & NS & ** & NS & NS & NS & NS & ** & NS & NS & NS & * \\
\hline & $\mathrm{NC}$ & 24.8 & 2.9 & 25.9 & 13.9 & 4.1 & 1.4 & 72.4 & 92.1 & 43.4 & 5.6 & 26.7 \\
\hline & ST & 25.6 & 3.2 & 25.8 & 13.7 & 4.0 & 1.5 & 73.4 & 83.3 & 48.5 & 5.9 & 31.3 \\
\hline & Significance & NS & * & NS & NS & NS & NS & NS & NS & NS & NS & NS \\
\hline \multirow[t]{6}{*}{2008} & MS & 21.4 & 4.6 & 28.9 & 13.8 & 3.3 & 1.6 & 75.0 & 107.6 & 51.9 & 6.6 & 98.0 \\
\hline & DD & 21.6 & 3.4 & 26.3 & 14.3 & 3.4 & 1.7 & 67.8 & 95.3 & 56.2 & 6.4 & 81.4 \\
\hline & Significance & NS & ** & * & NS & NS & NS & * & * & NS & NS & NS \\
\hline & $\mathrm{NC}$ & 21.6 & 3.9 & 27.2 & 14.2 & 3.5 & 1.7 & 73.2 & 98.7 & 51.1 & 6.7 & 92.4 \\
\hline & ST & 21.4 & 4.0 & 27.9 & 13.8 & 3.2 & 1.7 & 69.6 & 104.3 & 57.0 & 6.4 & 87.0 \\
\hline & Significance & NS & NS & NS & NS & NS & NS & NS & NS & * & NS & NS \\
\hline
\end{tabular}

${ }^{\mathrm{z}} \mathrm{MS}=$ micro sprinkler irrigation, $\mathrm{DD}=$ double-lateral drip irrigation, $\mathrm{NC}=$ no groundcover with herbicide control of weeds, ST $=$ in-row wheat straw mulching.

${ }^{y} \mathrm{~N}=$ nitrogen, $\mathrm{P}=$ phosphorus, $\mathrm{K}=$ potassium, $\mathrm{Ca}=$ calcium, $\mathrm{Mg}=$ magnesium, $\mathrm{S}=$ sulfur, $\mathrm{l} \mathrm{g}^{\mathrm{kg}} \mathrm{g}^{-1}=0.1 \%$.

${ }^{\mathrm{x}} \mathrm{B}=$ boron, $\mathrm{Fe}=$ iron, $\mathrm{Mn}=$ manganese, $\mathrm{Cu}=$ copper, $\mathrm{Zn}=\mathrm{zinc}, 1 \mathrm{mg} \cdot \mathrm{kg}^{-1}=1 \mathrm{ppm}$.

${ }^{w *}$ and ** indicate treatment effect is significant at $5 \%$ and $1 \%$ probability level, respectively, based on the $F$ test; nonsignificant effect is denoted by NS.

Table 5. Effects of double-lateral drip irrigation and straw mulch on soil protozoa in a sweet cherry orchard by the end of the 3 -year study at The Dalles, OR, in Fall 2008.

\begin{tabular}{lcccc}
\hline Treatment $^{\mathbf{z}}$ & $\begin{array}{c}\text { Flagellates } \\
(\text { counts } / \mathrm{g})^{\mathbf{y}}\end{array}$ & $\begin{array}{c}\text { Amoebae } \\
(\text { counts } / \mathrm{g})\end{array}$ & $\begin{array}{c}\text { Ciliates } \\
(\text { counts } / \mathrm{g})\end{array}$ & $\begin{array}{c}\text { Total protozoa } \\
(\text { counts } / \mathrm{g})\end{array}$ \\
\hline MS & 304 & 1827 & 10 & 2141 \\
DD & 165 & 1903 & 10 & 2078 \\
Significance $^{\mathrm{x}}$ & $\mathrm{NS}$ & $\mathrm{NS}$ & $\mathrm{NS}$ & $\mathrm{NS}$ \\
NC & 396 & 3657 & 8 & 4061 \\
ST & 72 & 73 & 11 & 156 \\
Significance & $*$ & $* *$ & $*$ & $* *$
\end{tabular}

${ }^{\mathrm{z}} \mathrm{DD}=$ double-lateral drip irrigation, $\mathrm{MS}=$ micro sprinkler irrigation, $\mathrm{NC}=$ no groundcover with herbicide control of weeds, $\mathrm{ST}=$ in-row wheat straw mulching.

${ }^{\mathrm{y}} 1$ count $/ \mathrm{g}=28.3495$ counts $/ \mathrm{oz}$.

${ }^{x *}$ and ** indicate treatment effect is significant at $10 \%$ and $5 \%$ probability level, respectively, based on the $F$ test; nonsignificant effect is denoted by ns.

statistically significant with DD and ST compared with MS and NC, respectively, by the end of study in Fall 2008 (data not presented). Contents of active or total fungi and bacteria were unaffected by DD or ST relative to their controls by the end of study (data not presented). It appeared that ST resulted in greater biomass of total bacteria and less biomass of total fungi note that ST did not increase soil organic matter or $\mathrm{C}$ content after 3 years of mulching with wheat straw. Straw materials were not incorporated into the soil in this study and the 3 -year period of experimentation was perhaps insufficient to generate changes in soil quality.

\section{Conclusions}

DD reduced annual irrigation water consumption by $47.6 \%$ to $58.2 \%$ on sweet cherry compared with MS during the 3 -year period. Straw mulch lowered irrigation water use by $9.7 \%$ on average relative to NC. Fruit yields or quality of firmness, size, and sugar at harvest were unaffected by DD relative to MS. Straw mulch increased fruit size by $0.6 \mathrm{~mm}$ on average relative to $\mathrm{NC}$, which could result in increases in grower profitability. DD increased the percentage of marketable fruit by $8.6 \%$ relative to MS. Leaf $\mathrm{P}, \mathrm{B}, \mathrm{Zn}$, and Fe concentrations were reduced with DD over MS. Switching from MS to DD can substantially reduce irrigation water use while maintaining comparable productivity of producing sweet cherry but long-term fertility needs might be different from for MS. Straw mulch had significant impacts on soil protozoa, decreasing flagellates and amoebae but slightly increasing ciliates. Straw mulch resulted in a soil microbial community with remarkably less protozoa. Overall, DD is a viable alternate irrigation system for already established producing sweet cherry orchards with limited water resources for irrigation. Shifting from NC to ST can reduce irrigation water use in addition to increasing protection of soil from erosion.

\section{Literature cited}

Anderson, R.V. and D.C. Coleman. 1977. The use of glass microbeads in ecological experiments with bacteriophagic nematodes. J. Nematol. 9:319-322.

Afolayan, S.O., T.A. Ewemoje, S.A. Lateef, and E. Ayayil. 2007. Performance evaluation of drip irrigation and fertigation system for sweet maize and Telfairia occidentalis. Adv. Materials Res. 18:177-185.

Babiuk, L.A. and E.A. Paul. 1970. The use of fluorescein isothiocyanate in the determination of the bacterial biomass of a grassland soil. Can. J. Microbiol. 16:57-62.

Bryla, D.R., J. Gartung, T. Trout, R.S. Johnson, and J.E. Ayars. 2005. Drip 
irrigation improves potential profits for growing peach. Proc. California Chapter Amer. Soc. Agron., Modesto, CA, 1-2 Feb. 2005.

Bryla, D.R., T.J. Trout, J.E. Ayars, and R.S. Johnson. 2003. Growth and production of young peach trees irrigated by furrow, microspray, surface drip, or subsurface drip systems. HortScience 38:1112-1116.

Combs, S.M. and M.V. Nathan. 1998. Soil organic matter, p. 53-58. In: Brown, J.R. (ed.). Recommended chemical soil test procedures for the north central region, North Central Region Res. Publ. No. 221. Univ. of Missouri, Columbia.

Darbyshire, J.F., R.E. Wheatley, M.P. Greaves, and R.H.E. Inkson. 1974. A rapid micromethod for estimating bacterial and protozoan populations in soil. Ecology 61:764-771.

Dehghanisanij, H., A. Naseri, H. Anyoji, and A.E. Eneji. 2007. Effects of deficit irrigation and fertilizer use on vegetative growth of drip irrigated cherry trees. J. Plant Nutr. 30:411-425.

Engin, H., F. Sen, G. Pamuk, and Z. Gokbayrak. 2009. Investigation of physiological disorders and fruit quality of sweet cherry. European J. Hort. Sci. 74:118-123.

Fereres, E., D.A. Goldhamer, and L.R. Parsons. 2003. Irrigation water management of horticultural crops. HortScience 38:1036-1042.

Forge, T.A., E. Hogue, G. Neilsen, and D. Neilsen. 2003. Effects of organic mulches on soil microfauna in the root zone of apple: Implications for nutrient fluxes and functional diversity of the soil food web. Appl. Soil Ecol. 22:39-54.

Gavlak, R.G., D.A. Horneck, and R.O. Miller. 1994. Plant, soil and water reference methods for the western region. Univ. of Alaska, Fairbanks.

Ingham, E.R. and D.A. Klein. 1984. Soil fungi: Relationships between hyphal activity and staining with fluorescein diacetate. Soil Biol. Biochem. 16:273-278.

Khan, S.A., R.L. Mulvaney, and R.G. Hoeft. 2001. A simple soil test for detecting sites that are nonresponsive to nitrogen fertilization. Soil Sci. Soc. Amer. J. 65:1751-1760.

Jensen, M.E., J.L. Wright, and B.J. Pratt. 1971. Estimating soil moisture depletion from climate, crop, and soil data. Trans. Amer. Soc. Agr. Eng. 14:954-959.

Jury, W.A., W.R. Gardner, and W.H. Gardner. 1991. Soil physics. 5th ed. Wiley, New York.

Kuehl, R.O. 1994. Statistical principles of research design and analysis. Duxbury Press, Belmont, CA.

Laurent, A.S., I.A. Merwin, and J.E. Thies. 2008. Long-term orchard groundcover management systems affect soil microbial communities and apple replant disease severity. Plant Soil 304:209-225.

Leece, D.R. 1976. Diagnosis of nutritional disorders of fruit trees by leaf and soil analyses and biochemical indices. J. Austral. Inst. Agr. Sci. 42:3-19.

Lodge, D.J. and E.R. Ingham. 1991. A comparison of agar film techniques for estimating fungal biovolumes in litter and soil. Agr. Ecosyst. Environ. 34:131-144.

Mehlich, A. 1984. Mehlich 3 soil test extractant: A modification of Mehlich 2 extractant. Commun. Soil Sci. Plant Anal. 15:1409-1416.

Merwin, I.A., J.A. Ray, T.S. Steenhuis, and J. Boll. 1996. Groundcover management systems influence fungicide and nitrate- $\mathrm{N}$ concentrations in leachate and runoff from a New York apple orchard. J. Amer. Soc. Hort. Sci. 121:249-257.

Merwin, I.A., W.C. Stiles, and H.M. Vanes. 1994. Orchard groundcover management impacts on soil physical properties. J. Amer. Soc. Hort. Sci. 119:216-222.

Nakamoto, T. and M. Tsukamoto. 2006. Abundance and activity of soil organisms in fields of maize grown with a white clover living mulch. Agr. Ecosyst. Environ. 115:34-42.

Neilsen, D., P. Millard, L.C. Herbert, G.H. Neilsen, E.J. Hogue, P. Parchomchuk, and B.J. Zebarth. 2001. Remobilization and uptake of $\mathrm{N}$ by newly planted apple (Malus domestica) trees in response to irrigation method and timing of $\mathrm{N}$ application. Tree Physiol. 21:513-521.

Parker, M.L. and J. Hull. 1993. Orchard floor management affects cherry tree growth and moisture utilization. Acta Hort. 343:201-213.

Patten, K.D., M.E. Patterson, and E. Kupferman. 1983. Reducing surface pitting in sweet cherries. Post Harvest
Pomol. Nwsl. Vol. 1. Washington State Univ., Tree Fruit Res. Ext. Ctr., Pullman.

Patten, K.D., M.E. Patterson, and E. Kupferman. 2006. Reduction of surface pitting in sweet cherries. 19 Sept. 2010. <http://postharvest.tfrec.wsu.edu/ pgDisplay.php? article $=\mathrm{N} 1 \mathrm{I} 2 \mathrm{C}>$.

Paul, E.A. and F.E. Clark. 1988. Soil microbiology and biochemistry. Academic Press, San Diego.

Porritt, S.W., L.E. Lopatecki, and M. Meheriuk. 1971. Surface pitting-A storage disorder of sweet cherries. Can. J. Plant Sci. 51:409-414.

Sapers, G.M. 1994. Color characteristics and stability of nonbleeding cocktail cherries dyed with carotenoid pigments. J. Food Sci. 59:135-138.

Shock, C.C., E.B.G. Feibert, L.D. Saunders, and J. Klauzer. 2007. Deficit irrigation for optimum alfalfa seed yield and quality. Agron. J. 99:992-998.

Shribbs, J.M. and W.A. Skroch. 1986. Influence of 12 ground cover systems on young 'Smoothee Golden Delicious' apple trees: I. Growth. J. Amer. Soc. Hort. Sci. 111:525-528.

Sirrine, J.R., D.K. Letourneau, C. Shennan, D. Sirrine, R. Fouch, L. Jackson, and A. Mages. 2008. Impacts of groundcover management systems on yield, leaf nutrients, weeds, and arthropods of tart cherry in Michigan, USA. Agr. Ecosyst. Environ. 125:239-245.

Spreer, W., S. Ongprasert, M. Hegele, J. Wunsche, and J. Muller. 2009. Yield and fruit development in mango (Mangifera indica L. cv. Chok Anan) under different irrigation regimes. Agr. Water Mgt. 96:574-584.

U.S. Department of Agriculture. 1975. Soil survey of Wasco County, Oregon Northern Part. Natl. Coop. Soil Survey, Washington DC.

Watson, M.E. and J.R. Brown. 1998. pH and lime requirement, p. 13-16. In: J.R. Brown (ed.). Recommended chemical soil test procedures for the north central region. North Central Region Res. Publ. No. 221. Univ. of Missouri, Columbia.

Weather Underground. 2012. Local weather. 27 May 2012. <http://www. wunderground.com/history/airport/ KDLS/2008/7/1/MonthlyHistory.html>. 